\title{
The Role of Jurisprudence in the Interpretation of the Law and Its Conformity with the Realities in the Law of Iran and France
}

\author{
Rima Amiraghdam ${ }^{1}$, Gholam Ali Seifi Zeinab ${ }^{2}$, Ali Zare ${ }^{1} \&$ Mohsen Ghasemi ${ }^{3}$ \\ ${ }^{1}$ Department of Private Law, College of Law and Political Science, Science and Research Branch, Islamic Azad \\ University, Tehran, Iran \\ ${ }^{2}$ Department of Private Law, College of Law, Shahid Beheshti University, Tehran, Iran \\ ${ }^{3}$ Department of Private Law, College of Law, Central Branch, Islamic Azad University, Tehran, Iran
}

Received: July 12, 2016 Accepted: August 18, 2016 Online Published: September 29, 2016

doi:10.5539/jpl.v9n8p57 URL: http://dx.doi.org/10.5539/jpl.v9n8p57

\begin{abstract}
The jurisprudence position difference in common law systems and the written law among the sources of law requires the study of the jurisprudence role in the interpretation of the law, and its adaptation to the realities of society. In Iranian law, jurisprudence means identical judgments of prosecutors from additional resources and commentary, and accepting the fact that, it could create a legal rule seems unlikely. In France, with the approval of the separation of powers and criticizing the classical doctrine, it seemed unlikely, the jurisprudence has a legislative role, however, such an idea has been expanded with all law branches and it seems to be a balance between resources related to legislate on the one hand and jurisprudence, on the other hand. Since, the rules express the general rules and it is impossible to predict the detail in the legislative practically, it is jurisprudence that could provide interpretations consistent with realities and social requirements of the law, in a complementary and commentary role. In this paper, the relationship between jurisprudence and interpretation of the law, especially in cases where we face with the need to interpret the law and the effectiveness of position on the interpretation of the law and its adaptation with the realities of society by jurisprudence will be discussed. These matters are examined with the descriptive analysis method that shows the importance of them in highlighting the role of jurisprudence in the legal system.
\end{abstract}

Keywords: jurisprudence, situation, interpretation of law, social needs, legal developments

\section{Introduction}

However, in a comprehensive legal framework, the first and most important source of answers to all problems is "law", but today; it has become clear that, assuming the law is an unrealistic and imaginary assumption. All people have accepted that, the law never has all solutions in it in perfection, so, for resolving the hostility and exercising the right, there will be no choice but to interpret the law for the judge and the interpreter.

Variety and complexity of social relations, the progress of civilization, social and political circumstances, the need to resolve the conflict of laws, changes in literature and writing style of the laws, legislator's negligence and the development of science and technology, highlight the need for further interpretation of the law.

The legislator legislates and codifies the law, according to the conditions and issues that exist at the time of the legislation, and he tries to include all aspects and different issues, which are predictable in the text of the law, but human society is not experiencing stability and stillness, and it is constantly changing and evolving. The changing society cannot be managed by the former law, and with the growth of industry and technology, new issues and events will be created that are not foreseeable by the legislature and the law is incomplete or silent towards them and it is even possible, former law enforcement about them does not seem fair.

For this reason, the interpretation of law by the judge is inevitable and its solution is adapting the law to the existing realities that, in two parts, the dispute will be discussed. First, we will talk about the jurisprudence and interpretation of the law, their relationship and examples of the necessity of the law, and then we will discuss about the adaptation of the law with the facts, the position role in the interpretation of the law, and the jurisprudence role in presenting an interpretation in accordance with the facts. 


\section{Jurisprudence and Interpretation of the Law}

There is no doubt that, a Judge is responsible for law enforcement and the mission could force him to interpret the law and even enact a new rule making. In fact, it is necessary for the judge to clear the meaning of some texts; intellectually, the realm of interpretation is confined to clarify the true meaning of the law. The commentary does not add anything to the law, but in reality, the interpreter must choose between two and sometimes several possible senses. The real conflict, on different meanings, will take place before the judges and at the end, it is the responsibility of the Magistrate to choose one of those meanings, in this selection, the judge applies his creative power. ${ }^{1}$

Judges do not act in one same way, according to the case. If the letter of the law will not have the necessary clarity, judges, without being limited, freely, resort the preparation early action, to become aware of the original intentions of the legislator. If the law is silent on the case, then, the judges refer to the general principles of law. However, when there is a discussing of law interpretation or replacement of it,the judge, of whatever level, he is,can only be the originator of the law rule, through the proposed solution. The higher order of the judge, the higher his chances for follow-up initiative will be.

For example, the concept of fault that is the Article 2003 of the Civil Code of France and this article aims to explain civil liability. Over the years, the Civil Code 1804 France is suffering from "inevitable break time" and it is opened a new interpretation of it, that had more coordination with changes in society, especially on the concept of "public order and morality", contained in Article 6 of the Civil Code. Finally and in practice, some shortcomings felt and it created a kind of jurisprudence based on the judge. ${ }^{2}$ Similarly, in the definition of the term "damage" that is used in Article 201 of the Civil Code of Iran, and the definition of "subject to the transaction" that is anticipated in Article 200 of the Iran Civil Code, and Article 1110 of the French Civil Code. ${ }^{3}$

Given that, the law interpretation is the principal article of jurisprudence and the judge has the main role in this process, we study the relationship between jurisprudence and interpretation of the law and then, we raise examples of the need to interpret the law.

\subsection{Jurisprudence Relating to the Interpretation of the Law}

French Civil Code of 1804was required the judge to issue a verdict, in case of any legal dispute, which is referred to him. In fact, Article 4 of the Civil Code provided that "any judge who refrain to verdict under the pretext of silence, obscurity or brevity of the law, could be prosecuted due to refusing justice for the crime." In addition, the refusal of the justice administration is required criminal punishment (Article 434-7-1 of the Penal Code $)^{4}$ and the same concept can be seen in Article 3 of the Civil Procedure Code of Iran, which provides: "Judges shall address the claims according to law, verdicts or resolve the hostility. In case that the laws are conflicting and are not complete or clear, or even, when there will be no laws in the case, according to Islamic sources or authoritative rulings and legal principles that are not inconsistent with Sharia principles, they verdict the sentence case, and cannot refuse litigation proceedings or verdict, because of the silence excuse, defect, outline and conflict of laws. Otherwise, they will be recognized as not applying rights and will be sentenced to become punish."

Since the Judge is inevitable to verdict, and the law is always giving full access to the solution for him, therefore, he seeks his strength of mind. ${ }^{5}$ This is where; he can be allowed to decide with respect the judgment, by appealing to common sense and sense of justice. However, such solution may contain serious flaws, such as incoherence in the decision, because, what is fair for someone, may not be the same for others necessarily. Two same fights may have different solutions based on the personal impression of the judge to be fair. ${ }^{6}$

Within each field of law that is encoded (legislated) to some extent, the jurisprudence will be able to play an important role, not only within the application or interpretation of existing rules, but also, with legitimizing the rule of law, in a quiet section of the text. It is also the same on private international law largely. The same way for administrative rights, despite numerous and the unprecedented multitude of different texts, it is largely based on jurisprudence.

\footnotetext{
${ }^{1}$ Jacques Ghestin et Gilles Goubeaux, Traite de Droit Civil, Introduction Generale, Paris: L.G.D.J., 1977 , P318

${ }^{2}$ Lucienne Lafon, Jaqueline, La judicialisation de la politique en France, Inteanational Political Science Review, Vol 15, No.2, 1994, P137

${ }^{3}$ Katouzian,Nasser, civil rights, public contract rules, vol. 1, corporation Publishing, 1995, No. 222

${ }^{4} \mathrm{~F}$. TERRE, Introduction generale au droit. 7e ed, Paris, Dalloz, 2006, n351, P277

${ }^{5}$ V.not. sur le ca de doute, J., FCesaro, le doute en droit prive, These Paris ii, ed 2003, n 105

${ }^{6}$ F. TERRE, op.cit. P277
} 
The law cannot afford to resolve all matters: because sometimes, it is ambiguous, often incomplete and little by little, it is obsolete. Therefore, the law should be interpreted, completed and adopted. If the legislators refuse this important, who is better than a judge that is able to perform these three tasks (interpretation and completion and implementation of the law)? Article 4 of the French Civil Code and Article 3 of the Iran Civil Procedure Code have obliged the judge to verdict, and even in silence, ambiguous or vague law, he is encouraged to perform these tasks. By implication, these laws have recognized the right to him to complete the law, if necessary, improve it and even change it according to necessity, when finding a solution to the case under investigation. ${ }^{7}$

However, the reality in the world of justice is different and it gives more and more aware of the different manifestations of court operations. In the event that the law lacked sufficient clarity, however, the judge had to sentencing. At first, out of necessity, the legislator was asked to explain the meaning of the Act. However, this practice was abandoned soon, because it was caused prolongation of the proceedings. Currently, this task is under the responsibility of the judge to interpret the law, and during interpretation, he may give a meaning to the law that is not consistent with the idea of the legislator. Ordinary courts had to complete the law. Relying on existing law, with logical reasoning, they have extracted the fundamental principles of civil rights, and rectified the legislative deficiencies. When the law becomes old, the court shows more boldness. They adapt them with new needs with the aid of flexible and practical writing of these texts. ${ }^{8}$

\subsection{The Necessity for Interpretation of the Law}

Despite the claims of the law drafters, and their happiness and joy from the glory, integrity and openness of the work that have made, the ambiguity, neglect, defects, silence and conflict in law is inevitable. There is no way to claim that the drafters of the law have created a work without any explanation with all their efforts and expertise, that can pre-respond all the questions that, in practice, will be raised for the attorney. ${ }^{9}$

Sometimes, in principle, the law has no verdict on the issue and the legal issue, obviously, this issue cannot be abandoned, but it should be solved by resorting to the interpretation of the problem. For example, Article 2 Iranian civil law has determined the task of implementing rules, within the country, however, law enforcement is unknown abroad, the source of this is that, sometimes the legislator has not organized and regulated the items related to a specific issue. In fact, when the legislator could, and should, have considered the items, he did not do it, or sometimes, the legislator has failed to predict the necessity of specific commands, and he has not appointed them.

The latter issue has an increasing growth, due to the rapid growth of social relations and the emergence of new and unpredictable issues in the scope of rights. Therefore, the theory of dynamic rights is justified because, it states rights are constantly being revived. ${ }^{10}$

The silence can be as a lack of foresight law on the issue, because, the legislator cannot predict from the beginning of any material reality, and he has no choice but to give the determination of these cases to the implementing law reference. ${ }^{11}$

About the silence of the law, the blank document holder on completing its contents can be examples.

According to the standards and customs of society, when a document is given to someone in a blank, the authority in writing and completing the terms and provisions of the text are given to the holder. Therefore, a white signature that is later if completed by the holder as receipts of amount or a right by the signatory, is predicated true, and is valid and the claim of forgery is excluded.

In a judgment of 281 branches, Tehran Family Court, wherehas been approvedin the appeal ofthe Court Branch 60 of Tehran province, with the demands of dowry demands that is, an ordinary document and the demanding raised the forgery claim, after the dispute, by the court, to the expert and confirming the assignment of signature to demanding, and white signature of the document by him, it is argued that, according to the standards and customs of society, when a document is delivered to someone in blank, the provisions of the text is given to that

\footnotetext{
${ }^{7}$ V .L. Husson, analyse critique de la method de lexegese, Arch, Phil Droit,1972, P115

${ }^{8}$ F. TERRE, op.cit., PP288-289

${ }^{9}$ Omidi, Jalil, rules of criminal law interpretation, Faculty of Law and Political Science at Tehran University, Fall 1998, No. 41, pp. 10 and 11

${ }^{10}$ Klecin, Hans, pure legal theory, translation Ismail Nematolahei, Second Edition, University Research Institute, 2012, p. 121

${ }^{11}$ Ibid., P 129
} 
person. ${ }^{12}$

The document without main contents is known "The White Seal" or "blank" in legal practice, and lawyers have justified its validity, based on legal theory. ${ }^{13}$

In this regard, in Article 10 of the Uniform Code of Geneva, it is stated that: "If a draft that was not complete when issued, will be completed contrary to the original agreement, not paying attention to that agreement cannot be reliably toward the holder of the draft, unless, the draft holder has gained such a draft with ill-intention, or committed a serious fault in its gaining."

The issuer empties some of the conditions and gives the document to the holder, in fact, he delegates him to fill the empty area, and usually, he does not give the full authority to the holder and make an appointment to fill the empty document.

If the first holder, contrary to the agreement, fills the draft out, this objection may not be invoked against the holder, in good faith.

In this judgment, as can be seen, the court document is the norms and customs of the community. According to the custom of a community, a blank document that is given to others is as granting power of attorney to that person to fill vacancies which, as stated above, we also raised legal theory, even, on commercial documents, in the proper sense.

Social convention is often shaped based on the behavior of the majority and since the majority of blank documents or white seal are as granting power of attorney, therefore, in all cases, this initial assumption can be considered, unless, another claim could be proved.

If the behavior of the majority, in which case, create abuse and social sensibilities change in that direction, or in a particular city, or in a particular class, such behaviors are common, according to the interpretation that can have based on situation, one can come to a different conclusion and if these factors are not addressed, there is not a correct interpretation of the judgment.

As can be seen, this judgment is issued in the case that the law is silent about it and can have different judgments during different time or place.

Law in brief is that the meaning of a word, in general, is not obtuse, but, hesitating between two or more things. ${ }^{14}$ Sometimes, the law, apparently, has not a defect, but, the sentence is insufficient. The brief can be due to several things ${ }^{15}$ and also may be related to the subject of the matter, its mandate, or both of them. One of the factors that, in many cases, will cause law in brief is the words with multiple meanings and so-called "common word".

This happens when, the field of speech and practical circumstances, none of them, will be a conducive enough for the meaning that must be considered. In this case, multiple meaning will be the origin of ambiguity, misunderstanding or lack of clarity and it is the commentator responsibility that, if possible, eliminates this obstacle. $^{16}$

For example, the concept of public order and good morals can be mentioned that, in the administrative, political, and economic and ... finds many faces and over time and keep pace with changes in society, may be changed. The judge should determine the rules' limitation of public order in accordance with the administrative, economic and ... in his time. In French law, with the passing years, a new interpretation of the Civil Code 1804 has raised that had more coordination by the evolution of society, in particular, about the concept of "public order and morality", enshrined in Article 6 of the Civil Code that makes the concept of it clear.

Of the brevity of the law, we can refer to the sentence "to the order of" in the Commercial Code. Endorsements are a way to transfer the rights associated with commercial documents and this mechanism was invented in the 16 th century, in Italy and before that, the draft was non-transferable.

\footnotetext{
${ }^{12}$ Branch 60 of Tehran Appeals Court, judgments No. 9209972130500303 dated 05/19/2013, judicial decisions review collection Tehran Province, May, 2013, p. 138

${ }^{13}$ Fakhari, Amir Hossein, pleadings Master of Business Law, University martyr Beheshti, the second semester 2007-2008

${ }^{14}$ Ghiasi, Jalaluddin, interpretation of criminal law, first edition, the center of Islamic Publications Bureau, Qom, 2000, p. 24.

${ }^{15}$ Muzaffar, Muhammad Reza, al-fiqh principles, vol. 2, Ismailian, Qom, pp. 195 and 196-Mozaffar, Mohammad Reza, Logic, Third Edition, Firoozabadi, Qom, 1400 AH, p 425

${ }^{16}$ Zh.Kalinoski, the interpretation of law (legal logic and legal informatics), translated by Hassan Habibi, printing, data, Tehran, 1994, Page 29
} 
The documents can be transferable when, next to the name of the holder, the sentence "to the order of" will be written, but, in the first part of Article 11 of the Geneva says, the draft can be transmitted with endorsements, whether the sentence "to the order of" is or not, and this is a change that denies any trace of the sentence "to the order of".

Commercial documents have the ability to transfer, but, naturally, they do not have this property, and by writing the non-transferable sentence, we can turn a document to non-transferable. If the holder of the document, which is non-transferable is written on it, in spite of this requirement, transfer the document to another, this transfer is civil not commercial. In the commercial transmission, if the holder will be faced with non-payment, he can refer to endorsements, but in civil transmission, he should litigate against the drawee, and he has no right to refer the endorser.

Article 312 of the Iran Commercial Code, this expression can be seen, but, in practice, it has no legal. By virtue of paragraph 1 of Circular No. 598-27/01/67 and the theory of two hundred and forty-eighth sessions of rights commissions' banks on 10/10/1998, crossing the phrase "to the order of" does not prevent transmission of the check.

Likewise, the Department of Law and rules of the judiciary, in theory, number 6759/7 10.12.67, has announced that, due to the fact that, issuing checks, by crossing the words "to the order of" in the text of the check, has taken the right of endorsements and the transfer from the holder, and this is accepted by the holder, and in fact, the holder character was fundamental for receiving the check before the parties, transfer of such a check is not legal and proper and as a result, the holder or the next owners have not the right of recourse to the bank or the court to collect a check.

In jurisprudence, for example, in a judgment of the Legal Branch 80 of Tehran's General Court, that was confirmed in the appeal, in Branch 13 of the Tehran Appeals Court, the court considered crossing the sentence "in the order of", that the document holder character highlighted the issuer's opinion, therefore, the holder did not know after the transfer, the beneficiary in the case. ${ }^{17}$

\section{Jurisprudence and Legal Developments and Its Conformity with Facts}

Another magistrate's duties are adopting the law to the facts changes; in fact, due to constant contact with reality, the courts have created rules that compared with the law, they are more equitable and are more compatible with practical needs. Jurisprudence has the possibility of keeping pace with social developments and can reduce aging and infringement effectively; in fact, it is a combination of power and justice that has not the dryness and the rigor of the law, and the ambiguity of justice. It is vibrant and succulent laws and a flexible sapling. ${ }^{18}$

According to the jurisprudence role in the interpretation of the law, here, we review the changes in law, compliance of law with the existing reality and the role of jurisprudence in it. First, the concept of position and influence in the interpretation of the law and the role of jurisprudence in providing an interpretation consistent with the needs and realities of the society are raised.

\subsection{Situation and Its Impact on the Interpretation of the Law}

In semantics, situation is considered a space that the time is flowing in it. Forth has considered the position as one of the tools used by linguist or it is better to say, he has considered it as one of language describing method, and he has presented the analysis of language stages based on the position.

Haymz has considered the coordinates for the position to imitate the Forth that is relevant in interpreting the meaning of a dialogue. In this regard, he referred to the speaker, the listener, theme, position of time and location, communication channel, code, form of event and messages, and in his subsequent revisions, he added those present and witnessed of the conversation, valuation tools and the purpose of the conversation to the initial coordinates.

What Haymz had raised, Lewis has stated in the form of more coherent and more list, but with the same attention to show the role of tissue-linguistic in understanding the text: The possible world may be considered as a coordinate to interpret forms such as Imagine that. .., almost like ..., it can be understood that ...; time is considered to understand forms, such as today, tomorrow, next week. The listener should receive the time of sentence production to understand the speaker time; the place, to understand indicators such as here, there and adverbs of place such as over there, here and ... the audience should pay attention to the point to understand the

\footnotetext{
${ }^{17}$ Branch 13 of the Tehran Appeals Court, judgments No. 9209970221300149 dated 12/5/2013, Tehran Province Appeals of judicial decisions, the precursor, Page 165

${ }^{18}$ KatouzianNasser, philosophy of law, vol. 2, the corporation published, first edition, 1998, p. 581
} 
speaker's purpose; speaker to understand the forms such as "I" and "we", the audience for understanding forms, such as "you", in relation to the peculiarities of the speaker and the audience, it must be said that, in this regard, the coordinate of others to understand forms such as "they" and "he" is also important that, in the expression of Lewis, it has been neglected. On the other hand, it should be noted that the simplicity of these forms, should not hide the complexity of their application. Because only if, correct reference of the coordinates can be understood that, the audience and the text creator have unit environmental knowledge or experiences; the mentioning case to understand "this" and "that" and so on. In relation to this characteristic, the creator of audience should have an equal environmental knowledge so that the mentioning case will be able to reveal clearly them. ${ }^{19}$

Regarding the effect of situation, Article 38 of the Islamic Penal Code of Iran in 2013 can be pointed out that stated the mitigating factors are as follows: "... e - repentance, good record and specific conditions of the accused such as aging or disease ...... "It is the final section of Article 22 of the IPC 70 that cases have been added to the mitigating factors ${ }^{20}$ and is it that everything in this ward cited the story of the situation impact in determining the sentence of the person?

The effect of situation can also be mentioned in paragraph (a) Note 6 of the Law Concerning the reform of provisions relating to divorce, which states that "if the wife does works which have been legally responsible for them by the order of the husband or intention of donations, and it proves to the court, the court will calculate the fee that has been done, and will sentence to pay them."

This paragraph of the note speaks on remuneration, in the Iranian legal system, the principle is no freewill and the claim of free practice must prove it, but in judgments of justice, it is observed that the principle of no freewill, sometimes, changes its place in the practice of donations by doing household chores by women in Iranian family, and these are interpretations thatare formed under the influenced by the situation and the time, place and other factors.

\subsection{The Role of the Jurisprudence in Interpretation of the Law in Accordance with the Facts}

According to the concept of situation and the impact that it can have on the interpretation of the law, we can say, if the presented interpretation of the law will not be in accordance with the realities of the economic, social and ..., it is not efficient and since, the modification or amendment of the law takes time, this is a jurisprudence that could provide an appropriate interpretation and consistent with the realities of that time, and meet the legal rules' objective in pursuit of "efficiency", and similar verdicts in similar claims and enforcement is the realization of justice and legal security and is the standards to reach the optimum in terms of economic analysis. $^{21}$

Despite that, the stability of legal relations is an important element of legal security, but it should not be considered as a license for not moving the rights. To organize social life, rights must be transformed by the evolution of reality. Jurisprudence should help with bold interpretation of the rules, and adapt the old rules with new issues and events. ${ }^{22}$ In principle, the implementation of the rights with the facts primarily is the responsibility of the legislator; however, typically, it is the judge that for the first time faces with inappropriate law and understands it. He can apply a rule that knows it is inappropriate, but demands the intervention of the legislature to amend the rule. After many doubts about the inclusion of some heavy criminal provisions in contracts , French jurisprudence could force the French legislative to amend articles 1152 and 1231 of the Civil Code by this way, and approve the law in July 9, 1975, achieve the judicial review permission, in Criminal abusive conditions. ${ }^{23}$

Undoubtedly, the increased adversarial will lose its importance in front of their increasing diversity. Developments in legal sociology have helped to determine the causes of this phenomenon. That is why the knowledge has been developed to know the kind of adversarial. Through this typology, the role of the judge has undergone a remarkable transformation that, in French law, it has implied implicit comment that is the judge's idea that comes out of the process or it is the result of superior consultation and it will happen during susceptible

\footnotetext{
${ }_{19}$ Safavi, Kurush, Introduction to Semantics, third edition, chapter Mehr, Tehran 2004- Lowell, George, pragmatic, translated by Mohammad Amu Zadeh - Mahdiraji and Manuchehr Tavangar, first edition, Samt publisher, Tehran, 2004, quoted by Rostamian, Marzieh Tabatabaei, Seyed Kazem, a comparative study of situational context (cross-linguistic) Forth point of view, Haymz and Lewis with Sayagh Halyh, two expertise Journals ofinterdisciplinary researches of the Quran, Issue 4, summer 2011, pp. 32 and 33

${ }^{20}$ Edalat Khah, Mohammad Reza, detailed penal code, Majd Publications, first edition, 2011, pp. 107 and 108

${ }^{21}$ R. k. Vizheh, Mohammad Reza, legal security as a condition for judicial security, strategy journal, Issue 58, Spring 2011, Ss130-95

${ }^{22}$ Reaper, the maker of Rights, p. 12, quoting Ansari, Bagher, Role of the Judge in the evolution of the legal system, Mizan publisher, Second Edition, Winter 2013, p. 89

${ }^{23}$ Jacques Ghestin et Gilles Goubeaux, op.cit. , P322
} 
and disputed issues, or by requesting amendments in the legislation. ${ }^{24} \mathrm{An}$ increase in litigation indicates the role of the judge who could give opinions in accordance with the realities and needs, thereby minimizing costs and the implicit comment that is proposed in the French law, confirms this point.

Since ,Judges arbitrate the legal litigation and use the law, at the heart of the judicial phenomenon in the field of human relations, find themselves in different situations. If, the implemented legal rule has explicit and clear formulated, their task is relatively easy, and then, the judge's task will be almost mechanical. But as mentioned, usually, the things are not that simple. First, sometimes the letter of the law is doubtful and the legislator has not expressed his intention well: of course, sometimes, the legislature formulates it, during writing the text of a legal rule clearly, but he is not always successful in this task. Furthermore, facts that form the basis of a claim may be complex and may make a composition, which is not foreseen in the law, because the legislator is not able to deal with complex cases and determine a rule in advance governing them. In fact, he should not enter this area, otherwise, the law would be wider in fragmented and hardly understandable, and deficiency is always inevitable. ${ }^{25}$ Finally, the judge may face with the fact or the reality, which is completely hidden from the legislator's point of view; for example, an emerging phenomenon that is the result of life changes, following advances in knowledge. ${ }^{26}$

To change the legal rule, in order to adapt it to the evolution of the facts, the magistrate can use various ways, such as the mechanism of "assumptions". ${ }^{27}$ French Court has used the technique to adapt the responsibility for professional dealers, with new conditions of production and distribution. This assumption is extracted from 1643 and 1645 in French civil code, which prohibits seller, so that with the ill will, that is, with knowledge of hidden faults of the sales, limits his guarantee and overthrows full compensation for the damage caused by it. Coordinate the law, in cases, has been done in a way that a simple, practical premise is turned into a legal rule and that simple premise is that, in all cases, professional seller has awareness of product defects. For this reason, the French Court, initially, stated that, in this case, there is a "legal presumption" that, proving its contrary is the vendor's responsibility. Then, after a while, he went a little further and confirmed that, the assumption is non-rejectable and the vendor cannot prove otherwise. ${ }^{28}$

In Iranian law, in the verdict of Branch 86, a Tehran Legal Public Court that has been approved in Branch 10 of the Appeals Court in the province has been proposed that economic sanctions imposed by Western countries, can be considered as cases of force majeure, in the obligations that are subjected to sanctions. (Particularly in the case of supplying from those countries) Supplying of sanctioned goods, by some people, that is done in a certain way through specific communication, cannot be considered force majeure umbilical. Therefore, the unconditional best performance guarantee of the commitment that deposited to fulfill this commitment, cannot be used by the obligee, and in case of recording and cashing the warranty, its cost must be refunded to the committee. ${ }^{29}$

As it is easy to understand, if the sanction could be considered as a case of force majeure, in the years before sanctions or in the future, perhaps does not seem justified, and even this sentence in the above-mentioned judgment ".... and yet, it should be noted that, sanctions, with the time of its effectiveness and implementation of the subject were two different subjects, that in this regard, the power to the performance of the contract and predictability, by committed, must be paid the attention ... "that even, it considers the difference between the sanctions with the runtime and also these two time differences with the impact time. Then the interpretation of the judgment depends on effective factors, such as location, and the time we are at it.

The other words, of a judgment: "... the ability is the basis and criteria, where the standard is in public and commitments through, certain channels, by the power and capabilities based on specific and unconventional communication, cannot be the basis for ability" that the conventional measure in implementing the commitments will be grounded, and the convention is usually a common trade in its particular field.

\section{Conclusion}

From what was said, it was understood that law is an incomplete order and we cannot find all solutions in law.

\footnotetext{
${ }^{24}$ F. TERRE, op.cit. , P282

${ }^{25} \mathrm{~V}$, aussi LESCOT, Les Tribunaux en face de la carence du legislateur, JCP, 1966,I , 2007

${ }^{26}$ F. TERRE, op.cit. , P275

${ }^{27}$ Les Presumptions

${ }^{28}$ Raper, former, p. 13, quoting Ansari, Bagher, previous source, p. 88

${ }^{29}$ Branch 10 of the Tehran Appeals Court, judgments No. 9209970221000229 , Tehran Province Appeals of judicial decisions, the precursor, pp. 158 and 159
} 
The need for dispute resolution and justice requires the necessity to interpret. More importantly, society and its realities are dynamic, law has a static discipline, and this is the power of jurisprudences that can provide an interpretation, according to the realities and with the help of law interpretation, especially in cases, where the law interpretation is necessary, such as defects, silence, brevity, ambiguity and conflict of laws. Thus, the judge has to interpret the law, and it can be said that the most basic form factor of jurisprudence is an interpretation of the law, that examples of judicial judgments were expressed from the law interpretation necessity and on the other hand, sometimes, the legislature accepts a policy arising from jurisprudence, after the law is passed.

Jurisprudence is an important factor in achieving legal order, because the use of similar past decisions causes the achieving justice and legal security and we must admit that the role of jurisprudence cannot be ignored and, in a sense, judgment, it is the source of life in the law.

Given that situation and the factors affecting it, including the time, place, and audience etc. effect in the interpretation of laws and judicial decisions, that the examples in this regard were made. It can be said that the jurisprudence can present interpretations consistent with the realities and needs of the community by using the influence of the situation in the interpretation. Therefore, the presented interpretation will be efficient and could lead to the advancement of the legal system and achieve the optimal point, from the perspective of economic analysis in social welfare. The evidence of jurisprudence impact on the evolution of the law and adapting it with the facts were examined.

\section{References}

Ansari, B. (2013, Winter). Role of the Judge in the evolution of the legal system (2nd ed.). Mizan Press.

Fakhari, A. H. (2007/2008). pleadings Master of Business Law, University martyr Beheshti.

Ghiyasi, J. (2000). interpretation of criminal law (1st ed.). the center of Islamic Publications Bureau, Qom.

Katouzian, N. (1995). civil rights, public contract rules (Vol. 1). corporation publishing.

Katouzian, N. (1998). philosophy of law (Vol. 2). corporation Publishing, Printing.

Kelsen, H. (2012). pure legal theory, translation Ismail Nematolahei, Second Edition, Institute of Science.

Khah, E., \& Reza, M. (2011). detailed penal code (1st ed.). Majd Publications.

Mozafar, M. R. (1400). Logic (3rd ed.). Firoozabadi, Qom.

Mozafar, M. R. (n.d.). usul al-fiqh (Vol. 2). Ismailis, Qom.

Omidi, J. (1998, Fall). rules of interpretation of criminal law, Faculty of Law and Political Science at Tehran University.

Terre, F. (2006). Introduction generale au droit (7th ed.). Paris, Dalloz.

Vizheh, M. R. (2011, Spring). legal security as a condition for judicial security. strategy journal, (58).

Zh.Kalinoski. (1994). the interpretation of law (legal logic and legal informatics), translated by Hassan Habibi, first printing, Etelaat, Tehran.

\section{Copyrights}

Copyright for this article is retained by the author(s), with first publication rights granted to the journal.

This is an open-access article distributed under the terms and conditions of the Creative Commons Attribution license (http://creativecommons.org/licenses/by/4.0/). 